Artikel Penelitian

\title{
Hubungan Karakteristik Tempat Perindukan dengan Keberadaan Vektor Demam Berdarah Dengue di Kelurahan Jati Kota Padang
}

\author{
Nidia Ramadhani ${ }^{1}$, Nurhayati ${ }^{2}$, Djusmaini Ismail ${ }^{3}$
}

\begin{abstract}
Abstrak
Demam Berdarah Dengue (DBD) merupakan penyakit endemis di Kota Padang. DBD ditularkan oleh nyamuk sebagai vektornya. Keberadaan vektor DBD dalam suatu tempat perindukan dipengaruhi bahan dasar, permukaan, ukuran, letak, keadaan tutup dan warna. Tujuan penelitian ini adalah menentukan hubungan karakteristik tempat perindukan dengan keberadaan vektor DBD di Kelurahan Jati Kota Padang. Penelitian ini menggunakan desain analitik dengan metode cross sectional study pada 105 rumah di Kelurahan Jati, Kota Padang. Pengumpulan data dilakukan dengan cara observasi keberadaan vektor DBD di tempat perindukan di rumah penduduk kemudian dikelompokkan sesuai karakteristiknya. Hubungan antara variabel dianalisis dengan uji chi-square. Hasil penelitian menunjukkan karakteristik tempat perindukan vektor DBD berbahan dasar buatan sebesar $100 \%$, memiliki permukaan halus sebesar $91,7 \%$, berukuran besar sebesar $52,7 \%$, terletak di dalam rumah sebesar $86,1 \%$, terbuka sebesar $94,4 \%$, dan berwarna gelap sebesar $55,55 \%$. Analisis statistik menunjukkan terdapat hubungan bermakna antara ukuran dan keadaan tutup tempat perindukan dengan keberadaan vektor DBD, sedangkan permukaan, letak, dan warna tempat perindukan tidak menunjukkan hubungan yang bermakna dengan keberadaan vektor DBD. Keberadaan vektor DBD di Kelurahan Jati berkaitan dengan karakteristik tempat perindukan.
\end{abstract}

Kata kunci: DBD, vektor, tempat perindukan

\begin{abstract}
Dengue Hemorrhagic Fever (DHF) is still endemic in Padang, West Sumatra. DHF is transmitted by mosquitoes as vector. Existence of DHF vector in a breeding place affected by base material, surface, size, location, and color of breeding place. The objective of this study was to determine characteristic of breeding place and its relation with the existence of Dengue Hemorrhagic Fever (DHF) vector in Jati village, Padang. This study used an analytical design method of cross-sectional study on 105 houses in Jati village, Padang. Data collection is done by observing the presence of DHF vector breeding places in house of population and then classify breeding place based on its characteristics. The relationship between all variables was analyzed by Chi-Square test. Characteristics breeding places of DHF vector with artificial based material was $100 \%$, has a smooth surface was $91,7 \%$, large sized was $52,7 \%$, located inside the house was $86,1 \%$, open was $94,4 \%$, and dark color was $55,55 \%$. Statistical analysis showed there was a significant relationship between the size and state of the lid breeding places with the presence of DHF vector, while the base material, surface, layout, and color breeding places did not show significant correlation with the presence of DHF vector. The existence of DHF vector in Jati village is related to the characteristics of breeding places.
\end{abstract}

Keywords: DHF, vector, breeding places

Affiliasi penulis: 1. Prodi Profesi Dokter FK Unand (Fakultas Kedokteran Universitas Andalas Padang, 2. Bagian Parasitologi FK Unand, 3. Bagian Fisika FK Unand
Korespondensi: Nidia Ramadhani, Email:

nidiaramadhani@gmail.com,telp: 083181439250 


\section{PENDAHULUAN}

Demam Berdarah Dengue (DBD) atau Dengue Hemorrhagic Fever (DHF) adalah penyakit infeksi virus dengue yang ditularkan oleh nyamuk Aedes aegypti sebagai vektor utama dan Aedes albopictus sebagai vektor potensial. ${ }^{1,2}$ Penyakit ini sangat berbahaya karena dapat menyebabkan kematian. ${ }^{3}$

DBD merupakan masalah kesehatan masyarakat utama di negara yang berada pada kawasan tropis, terutama Indonesia, Myanmar, Sri Lanka, Thailand dan Timor Leste. Aedes aegypti tersebar luas baik di daerah perkotaan maupun daerah pedesaan. ${ }^{3}$ DBD di Indonesia pertama kali dilaporkan pada tahun 1968 di Jakarta dan Surabaya. Sejak itu, kasus DBD terus meningkat. Kejadian DBD terbanyak terjadi di daerah dengan tingkat kepadatan penduduk tinggi, seperti provinsi di Pulau Jawa, Bali, dan Sumatera. ${ }^{4}$

Kota Padang merupakan salah satu kota endemis DBD di Sumatera Barat. Berdasarkan data Dinas Kesehatan Kota Padang pada tahun 2011, kasus DBD terbanyak terjadi di wilayah kerja Puskesmas Andalas (140 kasus). Kelurahan Jati, yang berada di wilayah kerja Puskesmas Andalas, memiliki kasus DBD yang paling tinggi (23 kasus). ${ }^{5}$

Tingginya angka kejadian DBD berkaitan erat dengan keberadaan vektor. Salah satu faktor risiko terjadinya penularan DBD dan peningkatan kasus penyakit DBD adalah semakin berkembangnya penyebaran dan kepadatan vektor. Oleh karena itu, perlu dilakukan upaya menurunkan kepadatan vektor DBD dengan cara meminimalkan tempat perindukan vektor, menurunkan umur vektor, mengurangi kontak vektor dengan manusia agar risiko penularan DBD menjadi menurun. ${ }^{4}$

Sampai saat ini belum ditemukan vaksin dan obat yang ideal untuk mengobati $\mathrm{DBD}$, oleh karena itu pengendalian DBD yang tepat adalah melalui pemutusan rantai penularannya, yaitu dengan mengendalikan vektor DBD. Pengendalian vektor DBD dapat dilakukan dengan cara kimiawi, biologi, manajemen lingkungan, pemberantasan sarang nyamuk (PSN), dan pengendalian vektor terpadu. Pemberantasan Sarang Nyamuk Demam Berdarah
Dengue (PSN-DBD) merupakan cara yang paling efisien dan efektif agar rantai penularan DBD terputus. $^{4} \quad$ Tempat perindukan adalah tempat dimana nyamuk Aedes sp. meletakkan telurnya untuk berkembang biak. ${ }^{6}$ Ciri tempat perindukan yang lebih disukai nyamuk Aedes sp. untuk berkembang biak adalah tempat berwarna gelap, bahan yang terbuat dari tanah liat, dan berisi air jernih. ${ }^{7}$

Berdasarkan hal diatas, maka tempat perindukan mempengaruhi keberadaan vektor DBD. Oleh karena itu, perlu diteliti hubungan karakteristik tempat perindukan dengan keberadaan vektor DBD di Kelurahan Jati Kota Padang.

\section{METODE}

Penelitian yang dilakukan bersifat cross sectional study pada Maret 2013 sampai Maret 2014. Lokasi penelitian di Kelurahan Jati kota Padang sedangkan pemeriksaan jentik vektor DBD dilakukan di Laboratorium Sentral Fakultas Kedokteran Universitas Andalas. Sampel penelitian adalah rumah penduduk di Kelurahan Jati yang berjumlah 105 rumah. Cara pengambilan sample yaitu teknik multistage random sampling secara proporsional. Data yang diperoleh dikumpulkan dan diolah dengan menggunakan metode chi-square test.

\section{HASIL DAN PEMBAHASAN}

Hasil penelitian yang telah dilakukan pada Kelurahan Jati Kota Padang didapatkan karakteristik tempat perindukan di Kelurahan Jati berdasarkan bahan dasar, permukaan, ukuran, letak, keadaan tutup, dan warna dapat dilihat pada tabel 4. $100 \%$ vektor DBD di Kelurahan Jati ditemukan di tempat perindukan yang berbahan dasar buatan, 91,7\% vektor DBD ditemukan di tempat perindukan yang memiliki permukaan halus dan 8,3\% ditemukan pada permukaan kasar. $52,7 \%$ vektor DBD di tempat perindukan yang berukuran besar dan $47,3 \%$ vektor DBD di tempat perindukan berukuran kecil. $86,1 \%$ vektor DBD ditemukan di tempat perindukan yang berada di dalam rumah dan $13,9 \%$ vektor DBD ditemukan di tempat perindukan yang berada di luar rumah $94,4 \%$ vektor DBD ditemukan di tempat 
perindukan yang terbuka dan 5,6\% vektor DBD ditemukan di tempat perindukan yang tertutup. 55,55\% vektor DBD ditemukan di tempat perindukan yang berwarna gelap dan $44,45 \%$ vektor DBD ditemukan di tempat perindukan berwarna terang.

Hubungan bahan dasar tempat perindukan dengan keberadaan vektor DBD dapat dilihat pada tabel 5. Hasil penelitian didapatkan bahwa tempat perindukan berbahan dasar buatan terdapat vektor DBD berjumlah 36 buah (13,6\%), lebih sedikit dibandingkan dengan yang tidak terdapat vektor DBD berjumlah 228 buah $(86,4 \%)$. Dari data tersebut tidak dapat dilakukan analisis karena $100 \%$ vektor DBD ditemukan di tempat perindukan berbahan dasar buatan.

Tabel 6 menjelaskan hubungan permukaan tempat perindukan dengan keberadaan vektor DBD. Hasil penelitian yang didapatkan tempat perindukan yang memiliki permukaan halus terdapat vektor DBD berjumlah 33 buah $(13,4 \%)$, lebih sedikit dibandingkan dengan yang tidak terdapat vektor DBD berjumlah 214 buah (86,6\%). Dari hasil uji statistik antara permukaan tempat perindukan dengan keberadaan vektor DBD diperoleh $p$ value $0,712(p>0,05)$, dengan demikian tidak terdapat hubungan yang bermakna antara permukaan tempat perindukan dengan keberadaan vektor DBD di Kelurahan Jati, Kota Padang.

Tabel 7 menjelaskan hubungan ukuran tempat perindukan dengan keberadaan vektor DBD. Hasil penelitian didapatkan tempat perindukan berukuran besar yang terdapat vektor DBD berjumlah 19 buah $(23,5 \%)$, lebih sedikit dibandingkan dengan yang tidak terdapat vektor DBD berjumlah 62 buah (76,5\%). Dari hasil uji statistik antara ukuran tempat perindukan dengan keberadaan vektor DBD diperoleh $p$ value $0,002(p<0,05)$, dengan demikian terdapat hubungan yang bermakna antara ukuran tempat perindukan dengan keberadaan vektor DBD di Kelurahan Jati, Kota Padang.

Hasil penelitian mengenai hubungan letak tempat perindukan dengan keberadaan vektor DBD. pada tabel 8. Tempat perindukan yang terletak di dalam rumah terdapat vektor DBD berjumlah 31 buah $(12,7 \%)$, lebih sedikit dibandingkan dengan yang tidak terdapat vektor DBD berjumlah 214 buah (87,3\%). Dari hasil uji statistik antara letak tempat perindukan dengan keberadaan vektor DBD diperoleh $p=0,154$ $(p>0,05)$, dengan demikian tidak terdapat hubungan yang bermakna antara letak tempat perindukan dengan keberadaan vektor DBD di Kelurahan Jati, Kota Padang.

Hasil penelitian mengenai hubungan keadaan tutup tempat perindukan dengan keberadaan vektor DBD pada tabel 9. Tempat perindukan yang terbuka yang terdapat vektor DBD berjumlah 34 buah $(15,5 \%)$, lebih sedikit dibandingkan dengan yang tidak terdapat vektor DBD berjumlah 185 buah (84,5\%). Dari hasil uji statistik antara keadaan tutup tempat perindukan dengan keberadaan vektor DBD diperoleh $p$ value $0,049(p<0,05)$, dengan demikian terdapat hubungan yang bermakna antara keadaan tutup tempat perindukan dengan keberadaan vektor DBD di Kelurahan Jati, Kota Padang.

Tabel 10 menjelaskan hubungan warna tempat perindukan dengan keberadaan vektor DBD. Hasil penelitian didapatkantempat perindukan yang berwarna gelap yang terdapat vektor DBD berjumlah 20 buah (15\%), lebih sedikit dibandingkan dengan yang tidak terdapat vektor DBD berjumlah 113 buah (85\%). Dari hasil uji statistik antara warna tempat perindukan dengan keberadaan vektor DBD diperoleh $p$ value $0,504(p>0,05)$, dengan demikian tidak terdapat hubungan yang bermakna antara warna tempat perindukan dengan keberadaan vektor DBD di Kelurahan Jati, Kota Padang.

Keberadaan vektor DBD sama dengan Container Index $(\mathrm{Cl})$ yaitu sebesar $13,6 \%$. Angka tersebut melebihi standar $\mathrm{WHO}$ yaitu $\mathrm{Cl} \geq 5 \%$, sehingga Kelurahan Jati termasuk daerah yang berisiko tinggi untuk penularan DBD. ${ }^{8}$

Hasil penelitian di Kelurahan Bandar Purus Kota Padang, didapatkan $\mathrm{Cl}$ sebesar 29,13\%. ${ }^{9}$ Bila dibandingkan, $\mathrm{Cl}$ di Kelurahan Bandar Purus termasuk tinggi. Hal ini disebabkan metode penelitian yang dilakukan di Kelurahan Bandar Purus berbeda dengan di Kelurahan Jati. Penelitian di Kelurahan Bandar Purus melakukan pengambilan jentik sebanyak empat kali dalam empat bulan sedangkan penelitian di 
Kelurahan Jati melakukan pengambilan jentik hanya satu kali. Keberadaan vektor DBD di rumah penduduk dipengaruhi keberadaan tempat perindukan. Semakin banyak tempat perindukan di suatu rumah, maka akan semakin padat populasi vektor DBD. ${ }^{10}$

Berdasarkan hasil penelitian, didapatkan tempat perindukan yang mengandung vektor DBD di Kelurahan Jati Kota Padang tertinggi pada bak mandi $(61,1 \%)$, selanjutnya ember $(11,1 \%)$, tempat penampung air dispenser (13,9\%), drum (8,3\%), kaleng bekas $(2,8 \%)$, dan ban bekas $(2,8 \%)$. Pada penelitian yang dilakukan tahun 2004 dan 2007 juga mendapatkan bahwa bak mandi mengandung vektor DBD tertinggi. ${ }^{9}{ }^{11}$ Hal ini dapat disebabkan bahwa bak mandi memiliki volume yang besar, sehingga memudahkan vektor DBD meletakkan telurnya. ${ }^{12}$

Lain halnya dengan hasil penelitian yang dilakukan pada tahun 2013 di Kelurahan Ketapang Kota Probolinggo, bahwa 37,2\% vektor DBD lebih banyak ditemukan di drum. ${ }^{6} \mathrm{Hal}$ ini dapat disebabkan penduduk pada daerah tersebut masih menggunakan drum untuk menampung air untuk keperluan seharihari. Dapat dikatakan bahwa keberadaan vektor DBD di rumah penduduk tergantung pada kebiasaan menggunakan tempat penampung air sehari-hari.

Menurut hasil penelitian, didapatkan bahwa spesies vektor DBD yang ditemukan di rumah penduduk Kelurahan Jati Kota Padang 91,7\% adalah Aedes aegypti dan 8,3\% adalah Aedes albopictus. Hasil tersebut sama dengan penelitian yang dilakukan pada tahun 2004 yang mendapatkan 95\% spesies vektor DBD adalah Aedes aegypti. ${ }^{9}$ Tingginya persentase Aedes aegypti yang ditemukan sebagai vektor DBD disebabkan Aedes aegypti lebih banyak ditemukan di daerah perkotaan. ${ }^{2,13}$

Dari hasil penelitian didapatkan bahwa $100 \%$ vektor DBD ditemukan pada tempat perindukan berbahan dasar buatan. Hasil tersebut sama dengan penelitian yang dilakukan pada tahun 2004 dan 2012 bahwa $100 \%$ vektor DBD ditemukan di tempat perindukan berbahan dasar buatan. ${ }^{14,}{ }^{15}$ Adanya persamaan hasil penelitian tersebut dapat disebabkan tempat perindukan berbahan dasar buatan lebih banyak digunakan sebagai peralatan rumah tangga sehari-hari, sedangkan tempat perindukan alami tidak ditemukan di Kelurahan Jati.

Berdasarkan hasil penelitian, didapatkan bahwa $91,7 \%$ vektor DBD ditemukan pada tempat perindukan yang memiliki permukaan halus. Hasil tersebut berbeda dengan penelitian yang dilakukan pada tahun 2012, bahwa 57\% vektor DBD lebih banyak ditemukan di tempat perindukan yang memiliki permukaan kasar. ${ }^{16}$ Permukaan tempat perindukan yang kasar mempermudah vektor DBD untuk meletakkan telurnya. ${ }^{17}$

Adanya perbedaan persentase vektor DBD yang ditemukan ditempat perindukan di Kelurahan Jati Kota Padang dengan hasil penelitian pada tahun 2012 di sekolah dasar di Kecamatan Baturaja Timur, Ogan Komering Ulu, Sumatera Selatan disebabkan tempat perindukan yang berada di rumah penduduk di Kelurahan Jati Kota Padang lebih banyak yang memiliki permukaan halus sehingga persentase vektor DBD di tempat perindukan yang halus lebih tinggi dibandingkan di tempat perindukan yang kasar. ${ }^{16}$

Dari hasil penelitian didapatkan bahwa 52,7\% vektor DBD ditemukan pada tempat perindukan berukuran besar. Hasil tersebut sama dengan penelitian yang dilakukan pada tahun 2013 , sebanyak $66,93 \%$ vektor DBD lebih banyak ditemukan di tempat perindukan berukuran besar. $^{6}$ Lain halnya dengan penelitian yang dilakukan pada tahun 2012 yang mendapatkan hasil yang berbeda, yaitu sebanyak $80,2 \%$ vektor DBD ditemukan di tempat perindukan berukuran kecil. $^{16}$

Adanya perbedaan dari kedua hasil penelitian diatas disebabkan perbedaan definisi operasional yang menjadi patokan ukuran besar dan kecil sehingga mendapat persentase vektor DBD yang berbeda pada ukuran tempat perindukan. Bervariasinya tempat perindukan yang ditemukan tergantung lokasi, situasi, kondisi, kebiasaan maupun perilaku masyarakat dalam menggunakan wadah sebagai tempat penampungan air untuk kebutuhan sehari-hari. ${ }^{18}$

Berdasarkan hasil penelitian, didapatkan bahwa $86,1 \%$ vektor DBD ditemukan pada tempat perindukan yang berada di dalam rumah. Hasil 
tersebut sama dengan penelitian yang dilakukan pada tahun 2007 dan 2011 yang mendapatkan hasil 81\% vektor DBD lebih banyak ditemukan di tempat perindukan yang berada di dalam rumah. ${ }^{18,19} \mathrm{Hal}$ tersebut sesuai dengan teori bahwa Aedes aegypti sebagai vektor utama DBD dan pada penelitian juga didapatkan Aedes aegypti sebagai vektor utama DBD yang suka berada di dalam rumah (endofilik).

Dari hasil penelitian, didapatkan bahwa $94,4 \%$ vektor DBD ditemukan pada tempat perindukan terbuka. Hasil tersebut sama dengan penelitian yang dilakukan pada tahun 2011 dan 2012 yang mendapatkan hasil $90 \%$ vektor DBD lebih banyak ditemukan di tempat perindukan yang terbuka. ${ }^{16,18}$

Adanya persamaan hasil penelitian tersebut disebabkan pada tempat perindukan yang terbuka, vektor DBD lebih mudah untuk meletakkan telurnya dibandingkan dengan tempat perindukan yang tertutup. Walaupun tempat perindukan yang tertutup juga dapat ditemukan vektor DBD, dapat disebabkan sebelum dilakukan penelitian, tempat perindukan tersebut tidak ditutup dan nyamuk sudah meletakkan telurnya sehingga saat dilakukan penelitian, walaupun tempat perindukan dalam keadaan tertutup, telur nyamuk ditemukan sudah berkembang menjadi larva.

Berdasarkan hasil penelitian, didapatkan bahwa $55,55 \%$ vektor DBD ditemukan pada tempat perindukan berwarna gelap. Hasil tersebut sama dengan penelitian yang dilakukan oleh pada tahun 2011 dan 2012 bahwa 90\% vektor DBD lebih banyak ditemukan di tempat perindukan berwarna gelap. ${ }^{16,18}$ Hal ini sesuai dengan bionomik nyamuk Aedes sp. yang menyukai tempat perindukan berwarna gelap sebagai tempat bertelur. Tempat perindukan yang berwarna gelap membuat nyamuk tidak terlihat saat meletakkan telur sehingga nyamuk bebas meletakkan telurnya. ${ }^{20}$

Pada penelitian, vektor DBD ditemukan 100\% di tempat perindukan berbahan dasar buatan sehingga hubungan bahan dasar tempat perindukan dengan keberadaan vektor DBD tidak dapat dianalisis.

Dari hasil analisis, tidak terdapat hubungan yang bermakna antara permukaan tempat perindukan dengan keberadaan vektor DBD. Hasil tersebut sama dengan hasil penelitian yang dilakukan pada tahun 2012 bahwa tidak terdapat hubungan yang bermakna antara permukaan tempat perindukan dengan keberadaan vektor DBD. ${ }^{16}$ Lain halnya dengan penelitian yang dilakukan pada tahun 1994 bahwa terdapat hubungan yang bermakna antara permukaan tempat perindukan dengan keberadaan vektor DBD. ${ }^{20}$

Tidak terdapat hubungan yang bermakna antara permukaan tempat perindukan dengan keberadaan vektor DBD menandakan bahwa kebiasaan vektor DBD dalam meletakkan telurnya untuk bertelur tidak memerhatikan permukaan tempat perindukan kasar atau halus. Hal ini juga berkaitan dengan faktor lain yang memengaruhi vektor DBD untuk meletakkan telurnya, seperti warna tempat perindukan.

Menurut hasil analisis, terdapat hubungan yang bermakna antara ukuran tempat perindukan dengan keberadaan vektor DBD. Hasil tersebut berbeda dengan hasil penelitian pada tahun 2012 bahwa tidak terdapat hubungan yang bermakna antara ukuran tempat perindukan dengan keberadaan vektor DBD. ${ }^{16}$

Hasil yang didapatkan berbeda disebabkan penduduk Kelurahan Jati lebih banyak menggunakan tempat penampungan air yang kecil untuk keperluan sehari-hari sehingga jumlah tempat perindukan yang didapatkan berdasarkan ukurannya berbeda dengan hasil yang didapatkan Budiyanto. Ukuran tempat perindukan yang kecil namun memiliki warna yang gelap, akan memudahkan vektor DBD untuk meletakkan telurnya di tempat perindukan tersebut. ${ }^{16}$

Tempat perindukan yang dapat menampung banyak air juga membuat permukaan air menjadi lebih gelap. Selain itu, ukuran tempat perindukan yang besar dan volume air yang besar terdapat lebih banyak makanan yang dapat menunjang kelangsungan hidup larva. ${ }^{21}$

Hasil analisis, tidak terdapat hubungan yang bermakna antara letak tempat perindukan dengan keberadaan vektor DBD. Hasil tersebut sama dengan hasil penelitian yang dilakukan oleh pada tahun 2012, bahwa tidak terdapat hubungan letak tempat perindukan dengan keberadaan vektor DBD. ${ }^{22}$ Begitu pula dengan penelitian yang dilakukan pada tahun 
2012 bahwa tidak terdapat hubungan yang bermakna antara letak tempat perindukan dengan keberadaan vektor DBD. ${ }^{16}$

Letak tempat perindukan baik di dalam maupun di luar rumah tidak memengaruhi keberadaan vektor DBD karena nyamuk Aedes sp. memiliki bionomiknya masing-masing. Aedes aegypti lebih menyukai tempat perindukan yang berada di dalam rumah sedangkan Aedes albopictus lebih menyukai tempat perindukan di luar rumah.

Berdasarkan hasil analisis, terdapat hubungan yang bermakna antara keadaan tutup tempat perindukan dengan keberadaan vektor DBD. Hasil tersebut berbeda dengan hasil penelitian yang dilakukan pada tahun 2012 bahwa tidak terdapat hubungan keadaan tutup tempat perindukan dengan keberadaan vektor DBD. ${ }^{16,22}$

Salah satu penyebab penampungan air menjadi tempat perindukan adalah tidak tertutupnya penampungan air tersebut. Tempat perindukan yang tidak tertutup sangat berperan untuk vektor DBD meletakkan telurnya untuk berkembang biak. Bila tempat perindukan dalam keadaan tertutup dan tidak terdapat celah, akan mempersulit vektor DBD untuk meletakkan telurnya. ${ }^{23}$

Hasil analisis, tidak terdapat hubungan yang bermakna antara warna tempat perindukan dengan keberadaan vektor DBD. Hasil tersebut sama dengan hasil penelitian yang dilakukan pada tahun 2012 bahwa tidak terdapat hubungan warna tempat perindukan dengan keberadaan vektor $\mathrm{DBD}^{22}$ Berbeda dengan hasil penelitian pada tahun 2012, bahwa terdapat hubungan yang bermakna antara warna tempat perindukan dengan keberadaan vektor DBD. ${ }^{16}$

Adanya perbedaan hasil penelitian dapat disebabkan adanya faktor lain yang menyebabkan vektor DBD tetap ada di tempat perindukan berwarna gelap maupun terang, seperti ukuran. Ukuran tempat perindukan yang besar akan membuat nyamuk leluasa untuk meletakkan telurnya dibandingkan dengan tempat perindukan berukuran kecil. ${ }^{20}$

\section{Daftar Tabel}

Tabel 1. Distribusi frekuensi keberadaan vektor DBD pada tempat perindukan di rumah penduduk di Kelurahan Jati Kota Padang

\begin{tabular}{lcc}
\hline \multicolumn{1}{c}{ Vektor DBD } & f & $\%$ \\
\hline Positif & 36 & 13,6 \\
Negatif & 228 & 86,4 \\
\hline Jumlah & 264 & 100
\end{tabular}

Keterangan: $\mathrm{f}$ = frekuensi, $\%$ = persentase kejadian.

Tabel 2. Distribusi frekuensi jenis tempat perindukan yang mengandung jentik vektor DBD di Kelurahan Jati Kota Padang

\begin{tabular}{lcc}
\hline \multicolumn{1}{c}{ Jenis Tempat Perindukan } & $\mathbf{f}$ & $\%$ \\
\hline Bak Mandi & 22 & $61,1 \%$ \\
Tempat Penampung Air & 5 & $13,9 \%$ \\
Dispenser & & \\
Ember & 4 & $11,1 \%$ \\
Drum & 3 & $8,3 \%$ \\
Kaleng Bekas & 1 & $2,8 \%$ \\
Ban Bekas & 1 & $2,8 \%$ \\
Tempat Minum Burung & 0 & $0 \%$ \\
Toples Bekas & 0 & $0 \%$ \\
Helm Bekas & 0 & $0 \%$ \\
Tong & 0 & $0 \%$ \\
\hline Jumlah & 36 & $100 \%$ \\
\hline
\end{tabular}

Keterangan: $f=$ frekuensi, $\%=$ persentase kejadian.

Tabel 3. Distribusi frekuensi vektor DBD berdasarkan spesies di Kelurahan Jati

\begin{tabular}{lcc}
\hline \multicolumn{1}{c}{ Spesies } & $\mathbf{f}$ & $\%$ \\
\hline Aedes aegypti & 33 & 91,7 \\
Aedes albopictus & 3 & 8,3 \\
\hline Jumlah & 36 & 100
\end{tabular}

Keterangan: $f=$ frekuensi, $\%$ = persentase kejadian. 
Tabel 4. Distribusi frekuensi vektor DBD berdasarkan karakteristik tempat perindukan di Kelurahan Jati

\begin{tabular}{|c|c|c|c|}
\hline & & $f$ & $\%$ \\
\hline \multicolumn{4}{|c|}{ Bahan Dasar } \\
\hline - & Alami & 0 & 0 \\
\hline- & Buatan & 36 & 100 \\
\hline \multicolumn{4}{|c|}{ Permukaan } \\
\hline- & Kasar & 3 & 8,3 \\
\hline- & Halus & 33 & 91,7 \\
\hline \multicolumn{4}{|c|}{ Ukuran } \\
\hline- & Besar & 19 & 52,7 \\
\hline- & Kecil & 17 & 47,3 \\
\hline \multicolumn{4}{|l|}{ Letak } \\
\hline- & Dalam Rumah & 31 & 86,1 \\
\hline- & Luar Rumah & 5 & 13,9 \\
\hline \multicolumn{4}{|c|}{ Keadaan Tutup } \\
\hline- & Terbuka & 34 & 94,4 \\
\hline- & Tertutup & 2 & 5,6 \\
\hline \multicolumn{4}{|c|}{ Warna } \\
\hline- & Gelap & 20 & 55,55 \\
\hline- & Terang & 16 & 44,45 \\
\hline
\end{tabular}

Keterangan: $\mathrm{f}=$ frekuensi, $\%$ = persentase kejadian.

Tabel 5. Hubungan bahan dasar tempat perindukan dengan keberadaan vektor DBD

\begin{tabular}{|c|c|c|c|c|c|c|c|}
\hline \multirow{3}{*}{$\begin{array}{c}\text { Bahan } \\
\text { Dasar } \\
\text { Tempat } \\
\text { Perinduk } \\
\text { an }\end{array}$} & \multicolumn{4}{|c|}{ Keberadaan Vektor DBD } & \multirow{2}{*}{\multicolumn{2}{|c|}{ Total }} & \multirow{3}{*}{$\mathrm{p}$} \\
\hline & \multicolumn{2}{|c|}{ Ada } & \multicolumn{2}{|c|}{ Tidak Ada } & & & \\
\hline & f & $\%$ & f & $\%$ & f & $\%$ & \\
\hline Buatan & 36 & 13,6 & 228 & 86,4 & 264 & 100 & \\
\hline Alami & 0 & 0 & 0 & 0 & 0 & 0 & \\
\hline Total & 36 & 13,6 & 228 & 86,4 & 264 & 100 & \\
\hline
\end{tabular}

Tabel 6. Hubungan permukaan tempat perindukan dengan keberadaan vektor DBD

\begin{tabular}{|c|c|c|c|c|c|c|c|}
\hline \multirow{3}{*}{$\begin{array}{c}\text { Permukaan } \\
\text { Tempat } \\
\text { Perindukan }\end{array}$} & \multicolumn{4}{|c|}{$\begin{array}{c}\text { Keberadaan Vektor } \\
\text { DBD }\end{array}$} & \multirow{2}{*}{\multicolumn{2}{|c|}{ Total }} & \multirow{3}{*}{$\mathbf{p}$} \\
\hline & \multicolumn{2}{|c|}{ Ada } & \multicolumn{2}{|c|}{ Tidak Ada } & & & \\
\hline & $f$ & $\%$ & f & $\%$ & f & $\%$ & \\
\hline Halus & 33 & 13,4 & 214 & 86,6 & 247 & 100 & \multirow{2}{*}{0,712} \\
\hline Kasar & 3 & 17,6 & 14 & 82,4 & 17 & 100 & \\
\hline Total & 36 & 13,6 & 228 & 86,4 & 264 & 100 & \\
\hline
\end{tabular}

Tabel 7. Hubungan ukuran tempat perindukan dengan keberadaan vektor DBD

\begin{tabular}{|c|c|c|c|c|c|c|c|}
\hline \multirow{3}{*}{$\begin{array}{c}\text { Ukuran } \\
\text { Tempat } \\
\text { Perindukan }\end{array}$} & \multicolumn{4}{|c|}{$\begin{array}{c}\text { Keberadaan Vektor } \\
\text { DBD }\end{array}$} & \multirow{2}{*}{\multicolumn{2}{|c|}{ Total }} & \multirow[t]{3}{*}{ p } \\
\hline & \multicolumn{2}{|c|}{ Ada } & \multicolumn{2}{|c|}{ Tidak Ada } & & & \\
\hline & $f$ & $\%$ & $\mathbf{f}$ & $\%$ & f & $\%$ & \\
\hline Besar & 19 & 23,5 & 62 & 76,5 & 81 & 100 & \multirow{2}{*}{0,002} \\
\hline Kecil & 17 & 9,3 & 166 & 90,7 & 183 & 100 & \\
\hline Total & 36 & 13,6 & 228 & 86,4 & 264 & 100 & \\
\hline
\end{tabular}

Tabel 8. Hubungan letak tempat perindukan dengan keberadaan vektor DBD

\begin{tabular}{|c|c|c|c|c|c|c|c|}
\hline \multirow{3}{*}{$\begin{array}{c}\text { Letak } \\
\text { Tempat } \\
\text { Perindukan }\end{array}$} & \multicolumn{4}{|c|}{$\begin{array}{c}\text { Keberadaan Vektor } \\
\text { DBD }\end{array}$} & \multirow{2}{*}{\multicolumn{2}{|c|}{ Total }} & \multirow{3}{*}{ p } \\
\hline & \multicolumn{2}{|c|}{ Ada } & \multicolumn{2}{|c|}{ Tidak Ada } & & & \\
\hline & $\mathbf{f}$ & $\%$ & $f$ & $\%$ & $f$ & $\%$ & \\
\hline Dalam & 31 & 12,7 & 214 & 87,3 & 245 & 100 & \\
\hline rumah & & & & & & & 154 \\
\hline Luar rumah & 5 & 26,3 & 14 & 73,7 & 19 & 100 & 0,104 \\
\hline Total & 36 & 13,6 & 228 & 86,4 & 264 & 100 & \\
\hline
\end{tabular}

Tabel 9. Hubungan keadaan tutup tempat perindukan dengan keberadaan vektor DBD

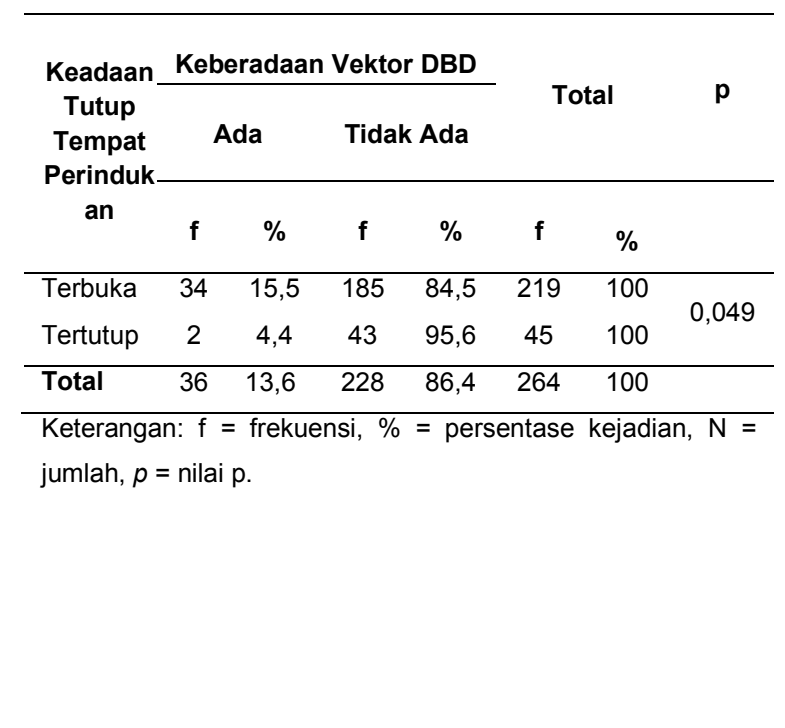


Tabel 10. Hubungan warna tempat perindukan dengan keberadaan vektor DBD

\begin{tabular}{|c|c|c|c|c|c|c|c|}
\hline \multirow{3}{*}{$\begin{array}{c}\text { Warna } \\
\text { Tempat } \\
\text { Perindu } \\
\text { kan }\end{array}$} & \multicolumn{4}{|c|}{ Keberadaan Vektor DBD } & \multirow{2}{*}{\multicolumn{2}{|c|}{ Total }} & \multirow{3}{*}{$\mathbf{p}$} \\
\hline & \multicolumn{2}{|c|}{ Ada } & \multicolumn{2}{|c|}{ Tidak Ada } & & & \\
\hline & $\mathbf{f}$ & $\%$ & $\mathbf{f}$ & $\%$ & $\mathbf{f}$ & $\%$ & \\
\hline Gelap & 20 & 15 & 113 & 85 & 133 & 100 & \\
\hline Terang & 16 & 12,2 & 115 & 87,8 & 131 & 100 & 0,504 \\
\hline Total & 36 & 13,6 & 228 & 86,4 & 264 & 100 & \\
\hline
\end{tabular}

\section{SIMPULAN}

Tidak terdapat hubungan yang bermakna antara bahan dasar, permukaan, letak, dan warna tempat perindukan dengan keberadaan vektor DBD di Kelurahan Jati Kota Padang.

Terdapat hubungan yang bermakna antara ukuran dan keadaan tutup tempat perindukan dengan keberadaan vektor DBD di Kelurahan Jati Kota Padang.

\section{UCAPAN TERIMA KASIH}

Terima kasih kepada semua pihak yang telah mengorbankan waktu, pikiran, dan tenaga dalam memberikan arahan dan masukan dalam penelitian.

\section{DAFTAR PUSTAKA}

1. Suhendro, Nainggolan L, Chen K, Pohan HT. Demam berdarah dengue. Dalam: Suroyo AW, Setiyohadi B, Alwi I, Simadibrata M, Setiati S, editor (penyunting). Buku ajar ilmu penyakit dalam jilid III. Edisi ke-5. Jakarta: Interna Publishing; 2009. hlm.2773-9.

2. Agoes R. Peran Serangga dalam ilmu kedokteran. Dalam: Natadisastra D, Agoes R, editor (penyunting). Parasitologi kedokteran: ditinjau dari organ tubuh yang diserang. Jakarta: EGC; 2009. hlm. 301-19.

3. World Health Organization (WHO). Dengue: guidelines for diagnosis, treatment, prevention and control - new edition. Geneva: WHO Press; 2009.

4. Kementerian Kesehatan RI. Modul pengendalian demam berdarah dengue. Jakarta: Kemenkes RI; 2011.
5. Dinas Kesehatan Kota Padang. Profil kesehatan Kota Padang tahun 2011 edisi 2012 (diunduh 19 Oktober 2012). Tersedia dari: URL: HYPERLINK http://dinkeskotapadang1.files.wordpress.com.

6. Wahyudi RI, Ginanjar P, Saraswati LD. Pengamatan keberadaan jentik Aedes sp pada tempat perkembangbiakan dan PSN DBD di Kelurahan Ketapang (Studi Di Wilayah Kerja Puskesmas Ketapang Dua). Jurnal Kesehatan Masyarakat. 2013;2(2).

7. Pratomo H, Rusdiyanto E. Studi populasi nyamuk demam berdarah dengue (DBD) di Kelurahan Widodomertani Yogyakarta.Jurnal Matematika, Sains, dan Teknologi. 2003;4(2).

8. National Institute of Communicable Diseases (NICD). Investigation \& control of outbreaks dengue fever \& dengue haemorrhagic fever. Dalam: Ramadhani MM, Astuty H. Kepadatan dan penyebaran aedes aegypti setelah penyuluhan DBD di Kelurahan Paseban, Jakarta Pusat. E Journal Kedokteran Indonesia. 2013;1(1).

9. Taufan F. Gambaran kepadatan vektor demam berdarah dengue (larva Aedes aegypti dan Aedes albopictus) di Bandar Purus Kodya Padang (skripsi). Padang. Fakultas Kedokteran Universitas Andalas. 2004.

10. Fathi, Soedjajadi K, Chatarina UW. Peran faktor lingkungan dan perilaku terhadap penularan demam berdarah dengue di Kota Mataram. Jurnal Kesehatan Lingkungan. 2005;2(21):1-10.

11. Nurwiyeni. Perbedaan faktor-faktor yang berhubungan dengan kejadian demam berdarah dengue di daerah endemis dan non endemis (skripsi). Padang. Fakultas Kedokteran Universitas Andalas. 2007.

12. Ramadhani MM, Astuty H. Kepadatan dan penyebaran Aedes aegypti setelah penyuluhan DBD di Kelurahan Paseban, Jakarta Pusat. eJurnal Kedokteran Indonesia. 2013;1(1):10-4.

13. Pramestuti N, Djati AP. Distribusi vektor demam berdarah dengue (DBD) Daerah perkotaan dan perdesaan di Kabupaten Banjarnegara. Buletin Penelitian Kesehatan. 2013;41(3):163-70.

14. Hasyimi H, Soekirno M. Pengamatan tempat perindukan Aedes aegypti pada tempat 
penampungan air rumah tangga pada masyarakat pengguna air olahan. Jurnal Ekologi Kesehatan. 2004;3(1):37-42.

15. Sari P, Martini, Ginanjar P. Hubungan kepadatan jentik Aedes sp. dan praktik PSN dengan kejadian DBD di sekolah tingkat dasar di Kota Semarang. Jurnal Kesehatan Masyarakat. 2012;1(2):413-22.

16. Budiyanto A. Karakteristik kontainer terhadap keberadaan jentik Aedes aegypti di sekolah dasar. Jurnal Pembangunan Manusia. 2012;6(1).

17. Sungkar S. Pemberantasan demam berdarah: Sebuah tantangan yang harus dijawab. Disampaikan dalam pidato pengukuhan guru besar tetap FKUI. 2007. Dalam: Ramadhani MM, Astuty H. Kepadatan dan Penyebaran Aedes aegypti Setelah Penyuluhan DBD di Kelurahan Paseban, Jakarta Pusat. E Journal Kedokteran Indonesia. 2013;1(1).

18. Widjaja J. Keberadaan Kontainer sebagai Faktor Risiko Penularan Demam Berdarah Dengue di Kota Palu, Sulawesi Tengah. Jurnal Aspirator. 2011;3(2):82-8.
19. Rosa E. Studi tempat perindukan nyamuk vektor demam berdarah dengue di dalam dan di luar rumah di Rajabasa Bandar Lampung. Jurnal Sains MIPA. 2007;13(1):57-60.

20. Sungkar $S$. Pengaruh jenis tempat penampungan air terhadap kepadatan dan perkembangan larva Aedes aegypti (tesis). Jakarta: Universitas Indonesia; 1994.

21. Kaira NL, Kaul SM, Rastologi RM. 1997. Dalam: Ramadhani MM, Astuty H. Kepadatan dan penyebaran Aedes aegypti setelah penyuluhan DBD di Kelurahan Paseban, Jakarta Pusat. E Journal Kedokteran Indonesia. 2013;1(1).

22. Astantri I H, Wardani RS, Sayono. Perbedaan keberadaan jentik di daerah endemis demam berdarah dengue berdasarkan profil kontainer (studi di Kota Semarang Jawa Tengah) (tesis). Semarang: Universitas Muhammadiyah Semarang; 2012.

23. Hasyimi M, Harmany N, Pangestu. Tempat-tempat terkini yang disenangi untuk perkembangbiakan vektor demam berdarah Aedes sp. Media Litbang Kesehatan. 2009;19(2):71-7. 